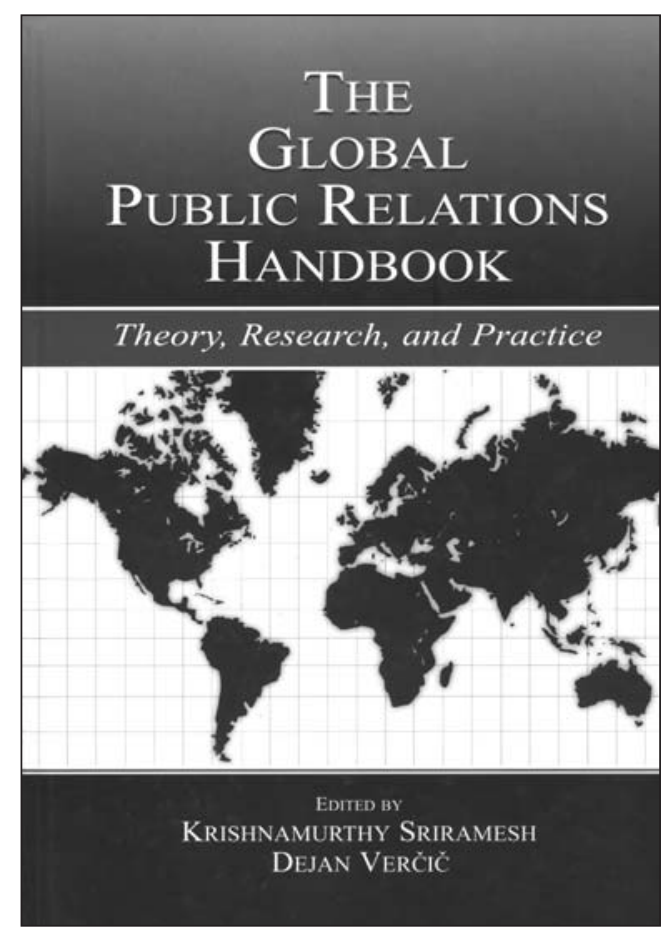

Krishnamurthy Sriramesh

e Dejan Vercic (orgs.)

The global Public Relations

handbook: theory,

research, and practice

Mahwah, New Jersey, USA:

Lawrence Erlbaum, 2003

576 páginas

Else Lemos

- Mestre em Ciências da Comunicação / Relações Públicas

- Especialista em Gestão Estratégica em Comunicação

Organizacional e Relações Públicas pela ECA-USP

- Graduada em Relações Públicas pela UFG

- Consultora em Comunicação Estratégica

para Pequenas e Médias Empresas

- elsesp@usp.br 


\section{Tão longe, tão perto}

$\mathrm{D}$ ois grandes pesquisadores, cinco continentes, dezesseis países representados, 25 capítulos, mais de quinhentas páginas e, finalmente, um conteúdo de valor inestimável: The Global Public Relations Handbook é, assim, uma obra de referência para alunos, professores e profissionais de Relações Públicas e Comunicação Organizacional. Do começo ao fim, o manual é o resultado de uma bem-sucedida iniciativa de reunir bons autores e um abrangente estudo sobre o status da pesquisa, prática profissional e contexto das Relações Públicas em todo o globo.

Segundo Sriramesh e Vercic, organizadores deste guia, o principal objetivo do livro é a análise contextualizada da teoria e prática de Relações Públicas em diferentes regiões do planeta, observando-as com relação a seu contexto sociocultural, político e midiático. Nesse sentido, trata-se de um projeto ambicioso cujo grande mérito está em reunir de forma competente uma ótima estrutura de análise, autores que são de fato representativos de suas regiões e países e, por fim, significativos estudos de casos na área de Relações Públicas.

A maior surpresa ao "viajar" por tantos capítulos está na orientação segura dos textos quanto à proposição inicial dos organizadores, buscando-se sempre a ligação entre contexto e atividade de Relações Públicas, suas práticas, pesquisa e ensino na área. A despeito das limitações próprias deste tipo de trabalho - é grande o desafio de reunir autores e as variações estilísticas na composição dos textos é comum, além de haver, em alguns casos, falta ou evidente abundância de conteúdo, fator influenciado por variáveis as mais diversas -, o guia resulta em um trabalho uniforme e consistente que é indispensável para aqueles que trabalham ou estudam Comunicação e Relações Públicas.

O melhor sentimento que The Global Public Relations Handbook traz ao leitor é o de pertencimento e identificação. Explico: estamos tão longe e, ao mesmo tempo, tão perto uns dos outros. Qualquer profissional, estudante ou acadêmico que leia um, cinco ou todos os estudos reunidos neste livro certamente se identificará, de alguma forma, com relatos e comentários cuja origem é geograficamente distante mas experiencialmente muito próxima.

O capítulo 4, por exemplo, fala que as Relações Públicas não foram bem-vindas no Japão por fatores culturais. O desafio cultural é também enfatizado na Rússia (capí- 
tulo 15), cujo maior dilema para o ensino de Relações Públicas está em seu grande território e múltiplas expressões culturais. O eterno embate terminológico e a legitimação da área são temas recorrentes: também no capítulo 4, o autor afirma que, na verdade, não há equivalente em japonês para o termo Relações Públicas, aliás, fenômeno semelhante em muitas outras partes do mundo. Alguém duvida? Além disso, o termo Relações Públicas não é muito usado na Holanda (capítulo 11), exceto num contexto negativo, e a maioria dos profissionais de Relações Públicas usam, em vez de Relações Públicas, os termos comunicação corporativa, gestão da comunicação ou comunicação ao referir-se a suas atividades, enfatizando o aspecto gerencial da atividade. E mais: ao contrário da maioria dos países que aparecem no manual, os gestores na Holanda consideram as Relações Públicas uma importante função gerencial que agrega valor às atividades organizacionais. Seria esse o sonho de todos que buscam a legitimidade desta área como teoria e prática? O que dizer do Egito (capítulo 9)? Ali, apesar de ser o termo Relações Públicas familiar à maioria dos egípcios, é mal compreendido e, para a maioria, restringe-se a atividades ligadas ao relacionamento com o consumidor ou que emprestam à organização um rosto sorridente e amigável.

A incompreensão quanto à função de Relações Públicas e seu lugar estratégico nas organizações é um dilema mais comum do que imaginamos: até grandes teóricos e pesquisadores como L. Grunig e J. Grunig (capítulo 16), ao apresentar seus princípios para a prática eficaz das Relações Públicas, criticamente afirmam que as Relações Públicas nos Estados Unidos ainda seguem o modelo de assessoria de imprensa. Em 1967, o Brasil (capítulo 17) tornou-se o primeiro país a regulamentar a profissão; entretanto, não foi a regulamentação suficiente em si mesma para legitimar a atividade profissional e a maioria dos gestores no Brasil continua a ver as Relações Públicas somente como uma função de relacionamento com a mídia. No Chile (capítulo 18), de modo semelhante, as Relações Públicas também não recebem o apoio dos gestores e continuam a ser vistas segundo o modelo de assessoria de imprensa. E a lista continua: em Singapura (capítulo 5), os gestores continuam a enfatizar as relações com a mídia e o modelo de assessoria de imprensa, relegando as Relações Públicas a um papel de apoio ao marketing. No Egito (capítulo 9), os autores afirmam que vendas e marketing freqüentemente se tornam a função principal de profissionais de Relações Públicas. Conclusão: em todos os relatos, as angústias são as mesmas.

Há ainda várias alusões às mudanças políticas que sucederam a Segunda Guerra e o fim das grandes ditaduras nas últimas décadas e suas influências sobre o exercício da atividade de Relações Públicas. Na Alemanha (capítulo 10), as Relações Públicas foram muito impactadas pela influência norte-americana pós Segunda Guerra; na Suécia (capítulo 12), como aconteceu em vários países, pode-se afirmar que as Relações Públicas modernas só começaram após a Segunda Guerra e, na Polônia (capítulo 13), a indústria de Relações Públicas parece estar contaminada pela bagagem do comunismo; por outro lado, esta mesma indústria também facilitou e acelerarou a transição política e econômica do país. 
A última parte do livro é um convite à reflexão sobre os grandes desafios da Comunicação e das Relações Públicas no contexto das organizações não-governamentais, agências internacionais de Relações Públicas e das atividades transnacionais de Comunicação. Outro assunto discutido é a importância da comunicação socialmente responsável e voltada para o desenvolvimento sustentável, tema que deve pautar a Comunicação das grandes multinacionais.

Finalmente, o manual traz à discussão a necessidade de um enfoque multicultural ao falar do ensino em Relações Públicas. Há, hoje, pouco material de regiões outras que não os Estados Unidos e alguns poucos países da Europa Ocidental. Muito do que se produz fora daqueles países não é divulgado ou traduzido e, como conseqüência, estudantes de diversas partes do mundo estão expostos apenas à literatura produzida nos EUA e grande parte da produção na área restringe-se aos referenciais teóricos propostos pela escola norte-americana. Este livro nos convida a ousar na contramão e, nesse sentido, The Global Public Relations Handbook é um grande livro. 